\title{
Fresh Fish Marketing Status in the Northwestern Bangladesh: Recommendations for Sustainable Management
}

\author{
Md. Mosaddequr Rahman ${ }^{1}$, Md. Akhtar Hossain ${ }^{1}$, Fatematuzzhura ${ }^{2}$, Shuraya \\ Tasnoova ${ }^{3}$, Ferdous Ahamed ${ }^{4}$, Md. Yeamin Hossain ${ }^{1 *}$, and Jun Ohtomi ${ }^{4}$ \\ ${ }^{1}$ Department of Fisheries, Faculty of Agriculture, University of Rajshahi, Rajshahi 6205, Bangladesh \\ ${ }^{2}$ Department of Agroforestry, Hajee Mohammad Danesh Science and Technology University, Dinajpur 5200, \\ Bangladesh \\ ${ }^{3}$ Department of Agricultural Economics, Faculty of Agriculture, Kagoshima University, Korimoto, Kagoshima \\ 890-0065, Japan \\ ${ }^{4}$ Faculty of Fisheries, Kagoshima University, 4-50-20 Shimoarata, Kagoshima 890-0056, Japan \\ *Email: yeamin2222@yahoo.com
}

\begin{abstract}
The present study was conducted in six fish markets of Rajshahi city during July 2011 to June 2012. The main objectives of this study was to investigate the marketing channel, marketing cost, marketing margin and the problems associated with fresh fish marketing in Rajshahi city in order to provide recommendations for better fish marketing system. Primary data were collected from 50 fish traders and 150 consumers through previously prepared questionnaires and the secondary source of information consist of published materials such as journals, textbooks, newspaper etc. The results of this study revealed 10 fish marketing channels in fresh fish marketing. The highest and lowest average fish price were recorded as USD 5.99/kg and USD $1.89 / \mathrm{kg}$ for cat fish and snake heads respectively. Average marketing cost was found as $6.27 \%$ of the final retail price. The market margins for all intermediaries varied from $23.37 \%$ for cat fish to $48.57 \%$ for prawn species with an average of $40.75 \%$. In contrast, producers' or fishermen's share ranged from $51.43 \%$ for prawn species to $76.63 \%$ for cat fish with an average of $59.25 \%$. The major problems associated with the fish marketing were- presence of long fish marketing channels, involvement of unnecessary middlemen, inadequate and unplanned infrastructural development, rough and unhygienic method of handling, improper and insufficient use of ice, contamination and lack of knowledge on quality aspects among fish traders, insufficient hygienic auction and retail spaces, absence of cold storage facility, inadequate drainage facilities and lack of modern weighing system. Introducing government fish shops, planned infrastructural development of fish markets, introduction of wholesaling and retailing facilities, provision for government and private funding assistance for fish traders, hygienic conditions of landing centers and markets, training and extension works in marketing and management of relevant market research, formation of fishermen or fish producers' cooperative society, sufficient auction and retail places, improved sanitation and drainage system, digital weighing system, government run fish transportation system with proper storage facilities are recommended for more efficient fresh fish marketing system in Rajshahi city.
\end{abstract}

Key words: Fresh fish, marketing, Rajshahi city, marketing channel, marketing cost, market margin, problems, recommendations. 
Md. Mosaddequr Rahman, Md. Akhtar Hossain, Fatematuzzhura, Shuraya Tasnoova, Ferdous Ahamed, Md. Yeamin Hossain and Jun Ohtomi / Our Nature (2012) 10: 128-136

\section{Introduction}

Fish is the most diverse group of vertebrates known to man with more than 20,500 species (Eyo, 1992). In Bangladesh, fish is the greatest source of animal protein providing $60 \%$ of the total animal protein intake and fisheries sector has been playing a dynamic role in alleviating protein shortage, providing jobs for unemployed youth, earning foreign currencies and socioeconomic development (FRSS, 2012). Total fish production was gradually grown up during the last 10 years in Bangladesh. In 2001-2002, the production was 1.89 million MT, whereas it was increased up to 3.06 million MT in 2010-11 (FRSS, 2012). About $97 \%$ of this production is marketed internally for domestic consumption while the remaining 3\% exported to the foreign (Rahman et al., 2009).

In marketing fresh fish passes through various market participants and exchange points before they reach the ultimate consumers. The marketing system and structure is one of the main circumstances of socio economic condition of the local people and production system of any area (Alam et al., 2010). It is a chain of various systems involved in marketing from production sector to consumer sector with intra-linkage and inter-linkage. At all stages in the marketing chain, fish has to be packed and un-packed, loaded and un-loaded to meet consumers demand. Each handling cost will not amount much but the sum total of all loading can be significant, depending on the length of chain (Ali et al., 2008). Subsequently, a greater difference in price paid between urban consumers at the end of the chain and farm gate price at the beginning of the chain resulted that can lead to a greater or wider market margin between the producer and the final consumer. However, when the market margin is high, it may be used to argue that producers or consumers are being exploited. Nonetheless, high margin cannot often be completely justified lest the costs involved are totally understood and reasonable (Ali et al., 2008). Fish supply and marketing suffer from various obstacles ranging from shortage of supply, price fluctuation due to drying up of the source, spoilage in transit etc. (Tomek and Robinson, 1981). Despite these, the people involved in the marketing of the fish appear to be on the increase because of increase in the population and therefore, the demand tends to be high and increase in concentration implies more scope for the middlemen to exploit either the consumers by charging high or the producer by paying them lower price (Tomek and Robinson, 1981). Moreover, market margin is an important indicator of market performance (Olukosi and Isitor, 1990). Often the middlemen performing the role of marketing are being accused of earning higher profits in the marketing system (Bryceson, 1993).

Fish marketing is completely maintained by the privet sector in Bangladesh where four different tires viz. primary, secondary, higher secondary and consumer market of marketing systems are observed in the process of distribution of fishes (Ahmed, 1983). Fish collectors commonly known as Mahajans or Aratdars procure fish from the catchers with the help of local brokers who get a profit margin or 
Md. Mosaddequr Rahman, Md. Akhtar Hossain, Fatematuzzhura, Shuraya Tasnoova, Ferdous Ahamed, Md. Yeamin Hossain and Jun Ohtomi / Our Nature (2012) 10: 128-136

commission from the Mahajans. However, the most serious marketing difficulties seem to occur in the remote communities owing to lack of transport, ice, poor road facilities and where the farmers are in a particularly weak position in relation to intermediaries (Rahman, 1997).

Rajshahi is one of the divisional cities of Bangladesh and is a city corporation covering an area of $96.69 \mathrm{~km}^{2}$ with a population of 294056 (BBS, 2005). Total fish production in Rajshahi district in 20102011 was 74943 MT which is $2.45 \%$ of the total fish production of Bangladesh (FRSS, 2012). Almost $100 \%$ of this production is marketed in fresh condition in local fish markets to meet up the demand of the local people. However, there were no studies found in the literature on the fresh fish marketing system in Rajshahi city. Thus the present study was designed to investigate the marketing channel, marketing cost and marketing margin and problems associated with fresh fish marketing in order to provide recommendations for efficient fish marketing system in the Rajshahi city.

\section{Materials and Methods}

\section{Study site and Data collection}

The present study was conducted in Rajshahi city, northwestern Bangladesh during July 2011 to June 2012. Data for the study was collected from six fish markets of Rajshahi city namely Binodpur fish market, Talaimari fish market, Shaheb bazar fish market, Laxmipur fish market, Horogram fish market and Shalbagan fish market. Both primary and secondary data were used during the study. Primary data were collected from 50 fish traders and 150 consumers through structured questionnaires. Secondary source of information consist of published material such as journals, textbooks, newspaper etc. Primary data included socio-economic variables such as price, cost, revenue, sales and problems allied with fish marketing.

\section{Market margin analysis}

Marketing margin is the difference between the price paid by consumer and that received by the producers and was calculated using the following formula-

Marketing margin $(\%)=($ Selling price Purchase price)/Selling price $\times 100$

\section{Results and discussion}

\section{Marketing channel}

Marketing channel refers to the sequence of stages involved in transferring product from the farm to the consumer (Shepherd, 1996). In most of the cases, the producers/fishermen sold their catch through intermediaries predominantly when the consumer markets were in distant places from the production areas. The common practice of channeling the catch/harvest was through the commission agents. 10 marketing channels were observed in the flow of fresh fish in Rajshahi city's fresh fish marketing (Fig. 1). Selection of a suitable marketing channel depended upon the volume and quality of fish catch, distance of the market and the requirements of the consumers.

Channel 1: Fishermen - Consumer

Channel 2: Fishermen/Producer - Retailer Consumer. 
Md. Mosaddequr Rahman, Md. Akhtar Hossain, Fatematuzzhura, Shuraya Tasnoova, Ferdous Ahamed, Md. Yeamin Hossain and Jun Ohtomi / Our Nature (2012) 10: 128-136

Channel 3: Fishermen/Producer - upon the species, marketing channel, Wholesaler - Retailer - Consumer

Channel 4: Fishermen/Producer - Aratdar

(Commission agent) - Retailer - Consumer

Channel 5: Fishermen/Producer - Aratdar

(Commission agent) - Wholesaler - Retailer

- Consumer

Channel 6: Fishermen/Producer

Wholesaler - Aratdar (Commission agent) -

Retailer - Consumer

Channel 7: Fishermen/Producer - Bepari Aratdar (Commission agent) - Retailer Consumer

Channel 8: Fishermen/Producer - Bepari Aratdar (Commission agent) - Wholesaler Retailer - Consumer

Channel 9: Fishermen/Producer - Aratdar (Commission agent) - Wholesaler - Aratdar (Commission agent) - Retailer - Consumer Channel 10: Fishermen/Producer - Bepari Aratdar (Commission agent) - Wholesaler Aratdar (Commission agent) - Retailer Consumer

\section{Price of Fish}

Different types of fish were marketed in the fish markets of Rajshahi city. Fish marketed here were usually caught from the Padma and other nearby rivers, beels, or produced in the ponds nearby the city. Consumers had to pay highest average price of USD $5.99 / \mathrm{kg}$ for buying cat fish followed by USD $5.10 / \mathrm{kg}$ for prawn species and USD $4.60 / \mathrm{kg}$ for featherbacks (Table 1). On the other hand, lowest market prices were recorded for snake heads as USD 1.89/kg followed by exotic carps (USD 2.06/kg) and carp species other than Indian major carps (USD $2.10 / \mathrm{kg}$ ). However, the price of fish was found to be varied considerably depending freshness, weight and source of fish, seasonal availability, consumer preference and demand.

\section{Marketing cost, market intermediaries and their market margins}

10 different types of marketing cost were involved in the fresh fish marketing (Fig. 2). Average total fish marketing cost was USD $0.18 / \mathrm{kg}$ fish. Highest $33.69 \%$ of the total marketing cost was for transportation and handling followed by fish container cost $(20.08 \%)$ and loading and unloading cost $(9.33 \%)$. The marketing cost ranged from $3 \%$ for cat fish to $9.46 \%$ for snake heads with an average marketing cost of $6.27 \%$ of the final retail price. However, the marketing cost is lower than that found by Rahman et al. (2009) in Khulna, Bangladesh as $20-25 \%$ and in Swarighat, Dhaka, Bangladesh as $15-20 \%$ (Alam et al., 2010). Variations in the marketing cost of fish can be attributed to different types of cost in different areas and also due to lower transportation cost in fish marketing in Rajshahi as the fish marketed here were almost exclusively produced locally.

Marketing margins are indicators of trends in costs, profits and services provided by farmers and food marketing firms (Hussain et al., 2003). This is the difference between what the consumer pays for food and what the farmer receives (Kohl and Uhl, 1972). The market margins for all intermediaries varied from $23.37 \%$ for cat fish to $48.57 \%$ for prawn species with an average of $40.75 \%$. The result of the present study is similar to that of Rahman et al. (2009) and Alam et al. (2010) who reported 
Md. Mosaddequr Rahman, Md. Akhtar Hossain, Fatematuzzhura, Shuraya Tasnoova, Ferdous Ahamed, Md. Yeamin Hossain and Jun Ohtomi / Our Nature (2012) 10: 128-136

the intermediary's share of $35-40 \%$ and 40 $45 \%$ in Khulna and Swarighat, Dhaka, Bangladesh, respectively. However, considering the average marketing cost of $6.27 \%$ it can be said that the intermediaries are making profit in fresh fish marketing in Rajshahi (Ali et al., 2008) and the consumers and the fish producers/fishermen are being exploited. On the other hand, producers' or fishermen's share ranged from $51.43 \%$ for prawn species to $76.63 \%$ for cat fish with an average of $59.25 \%$. However, the producer's or fishermen's share in fresh fish marketing in Rajshahi is relatively higher than that reported in Khulna and Khulna and Swarighat, Dhaka, Bangladesh as $40-45 \%$ and $30-40 \%$ respectively (Rahman et al., 2009; Alam et al., 2010). Nonetheless, the fish producer/fishermen are receiving only about half the price paid by the ultimate consumer and this is in consequence of the involvement of large percentage of the middlemen and commission agents reducing benefit of the fish producers/fishermen (Ahmed et al., 1993; Mazid, 1994).

The fishermen or fish producers are getting only $59.25 \%$ of the price paid by the consumers where market margin for intermediaries is very high $(40.75 \%)$ relative to the marketing cost $(6.27 \%)$. After harvest/catch all the fish passes a number of channels and intermediaries and are transported by road, by trucks, by bus, and by boats mainly using bamboo baskets and plastic containers. At each stage of marketing channel the quality of fish deteriorates and price increases. The major problems associated with the fish marketing in Rajshahi city were found as- presence of long fish marketing channels, involvement of unnecessary middlemen, inadequate and unplanned infrastructural development of the fish markets, rough and unhygienic method of handling, long exposure of fish to high temperature, improper and insufficient use of ice, contamination and lack of knowledge on quality aspects among fish traders, insufficient hygienic auction and retail spaces, absence of cold storage facility, overall unhygienic condition, inadequate drainage facilities, lack of modern weighing system. To save the fish producers/fishermen and consumers from the exploitation of middlemen and for more efficient fish marketing system in Rajshahi city the following measures could be recommended: the idea of government fish shops should be introduced so that instead of relying on middlemen, fish producers/fishermen and consumers could sell/buy fish directly in these shops. By introducing the government fish shops the marketing margins of middlemen could be substantially decreased and ultimately the share of the producers will be increased and the consumers can afford to buy fish at much lower price. Planned infrastructural development of the fish markets must be ensured, modern wholesaling and retailing facilities should be introduced, provision for government and private funding assistance for fish traders needs to be enhanced, hygienic conditions of landing centers and markets should be improved; training and extension works in marketing and management of relevant market research should be encouraged, formation of fishermen or fish producer's cooperative society should be encouraged, sanitation and 
Md. Mosaddequr Rahman, Md. Akhtar Hossain , Fatematuzzhura, Shuraya Tasnoova, Ferdous Ahamed, Md. Yeamin Hossain and Jun Ohtomi / Our Nature (2012) 10: 128-136

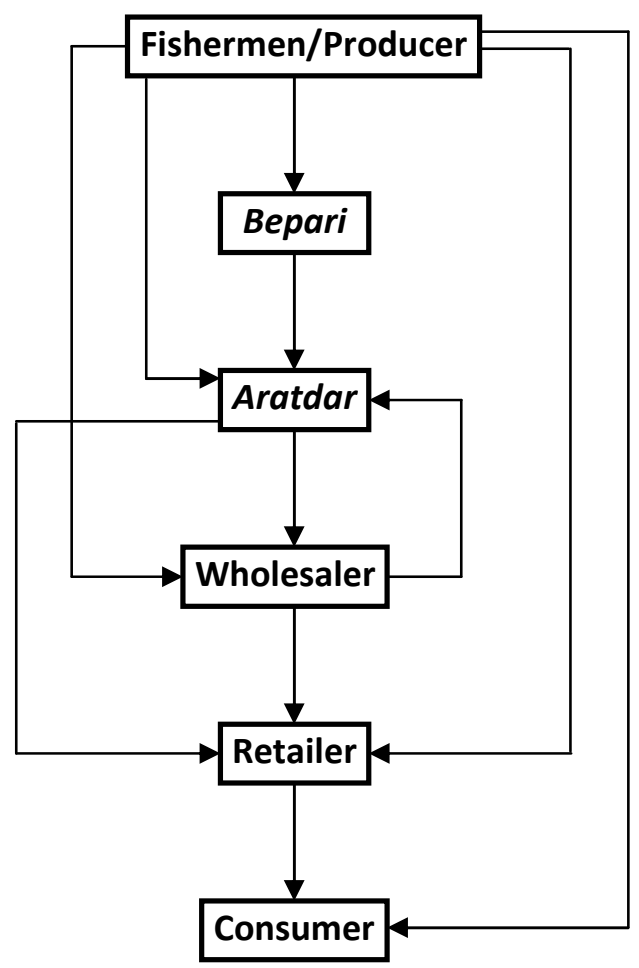

Figure 1. Schematic diagram showing the marketing channels of fresh fish in Rajshahi city.

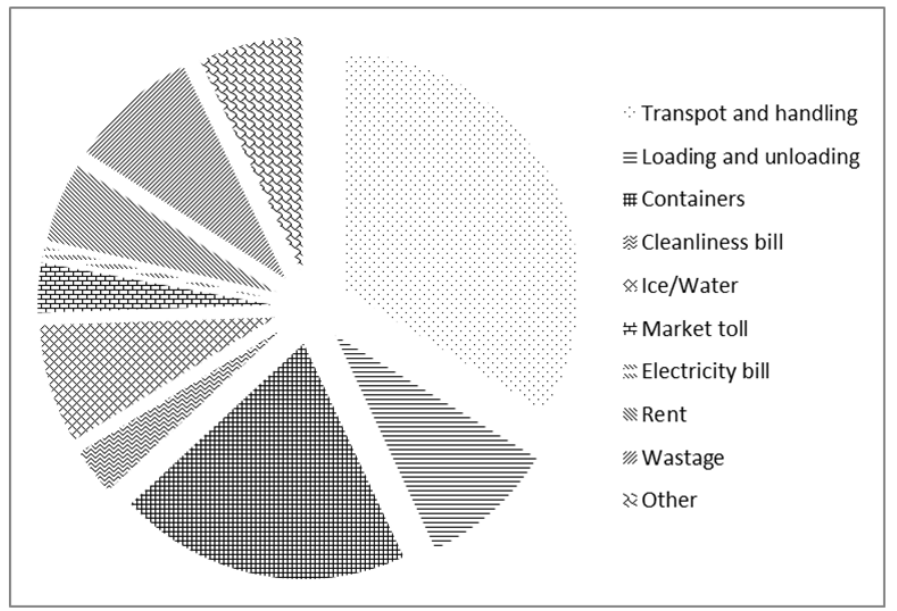

Figure 2. Marketing cost composition in fresh fish marketing in Rajshahi. 
Md. Mosaddequr Rahman, Md. Akhtar Hossain , Fatematuzzhura, Shuraya Tasnoova, Ferdous Ahamed, Md. Yeamin Hossain and Jun Ohtomi / Our Nature (2012) 10: 128-136

Table 1. Average weight of fish $(\mathrm{kg})$, average price at fishermen/ producer level $(\mathrm{Tk} / \mathrm{kg})$, average retail price (Tk/kg), producer's/fishermen's and intermediary's share on consumer's payment (\%) in fresh fish marketing in Rajshahi, NW Bangladesh.

\begin{tabular}{|c|c|c|c|c|c|c|c|}
\hline Fish group & Scientific name & 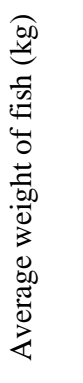 & 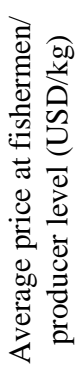 & 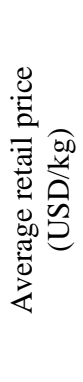 & 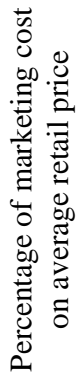 & 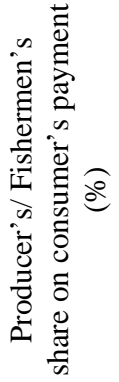 & 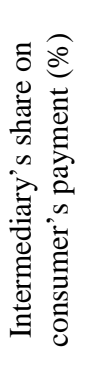 \\
\hline \multirow{4}{*}{$\begin{array}{l}\text { Indian } \\
\text { major carp }\end{array}$} & Labeo rohita & 1.6 & \multirow[t]{4}{*}{1.22} & \multirow[t]{4}{*}{2.18} & \multirow[t]{4}{*}{8.24} & \multirow[t]{4}{*}{55.96} & \multirow[t]{4}{*}{44.04} \\
\hline & Catla catla & 1.5 & & & & & \\
\hline & Cirrhinus mrigala & 0.7 & & & & & \\
\hline & Aristichthys nobilis & 0.83 & & & & & \\
\hline \multirow[t]{3}{*}{ Other carp } & Labeo calbasu & 0.65 & \multirow[t]{3}{*}{1.1} & \multirow[t]{3}{*}{2.1} & \multirow[t]{3}{*}{8.55} & \multirow[t]{3}{*}{52.38} & \multirow[t]{3}{*}{47.62} \\
\hline & Labeo bata & 0.15 & & & & & \\
\hline & Cirrhinus reba & 0.22 & & & & & \\
\hline \multirow[t]{8}{*}{ Exotic fish } & $\begin{array}{l}\text { Hypophthalmichtys } \\
\text { molitrix }\end{array}$ & 1.02 & \multirow[t]{8}{*}{1.06} & \multirow[t]{8}{*}{2.06} & \multirow[t]{8}{*}{8.67} & \multirow[t]{8}{*}{51.46} & \multirow[t]{8}{*}{48.54} \\
\hline & Ctenopharyngodon idella & 0.9 & & & & & \\
\hline & $\begin{array}{l}\text { Cyprinus carpio var. } \\
\text { communis }\end{array}$ & 0.69 & & & & & \\
\hline & $\begin{array}{l}\text { Cyprinus carpio var. } \\
\text { specularis }\end{array}$ & 0.65 & & & & & \\
\hline & Pangasius sutchi & 0.73 & & & & & \\
\hline & Oreochromis nilotica & 0.29 & & & & & \\
\hline & Oreochromis mossambicus & 0.31 & & & & & \\
\hline & Barbonymus gonionotus & 0.2 & & & & & \\
\hline \multirow[t]{6}{*}{ Cat fish } & Heteropneustes fossilis & 0.09 & \multirow[t]{6}{*}{4.59} & \multirow[t]{6}{*}{5.99} & \multirow[t]{6}{*}{3} & \multirow[t]{6}{*}{76.63} & \multirow[t]{6}{*}{23.37} \\
\hline & Clarias batrachus & 0.15 & & & & & \\
\hline & Batasio tengana & 0.04 & & & & & \\
\hline & M. tengara & 0.035 & & & & & \\
\hline & M. vittatus & 0.04 & & & & & \\
\hline & M. cavasius & 0.035 & & & & & \\
\hline
\end{tabular}


Md. Mosaddequr Rahman, Md. Akhtar Hossain, Fatematuzzhura, Shuraya Tasnoova, Ferdous Ahamed, Md. Yeamin Hossain and Jun Ohtomi / Our Nature (2012) 10: 128-136

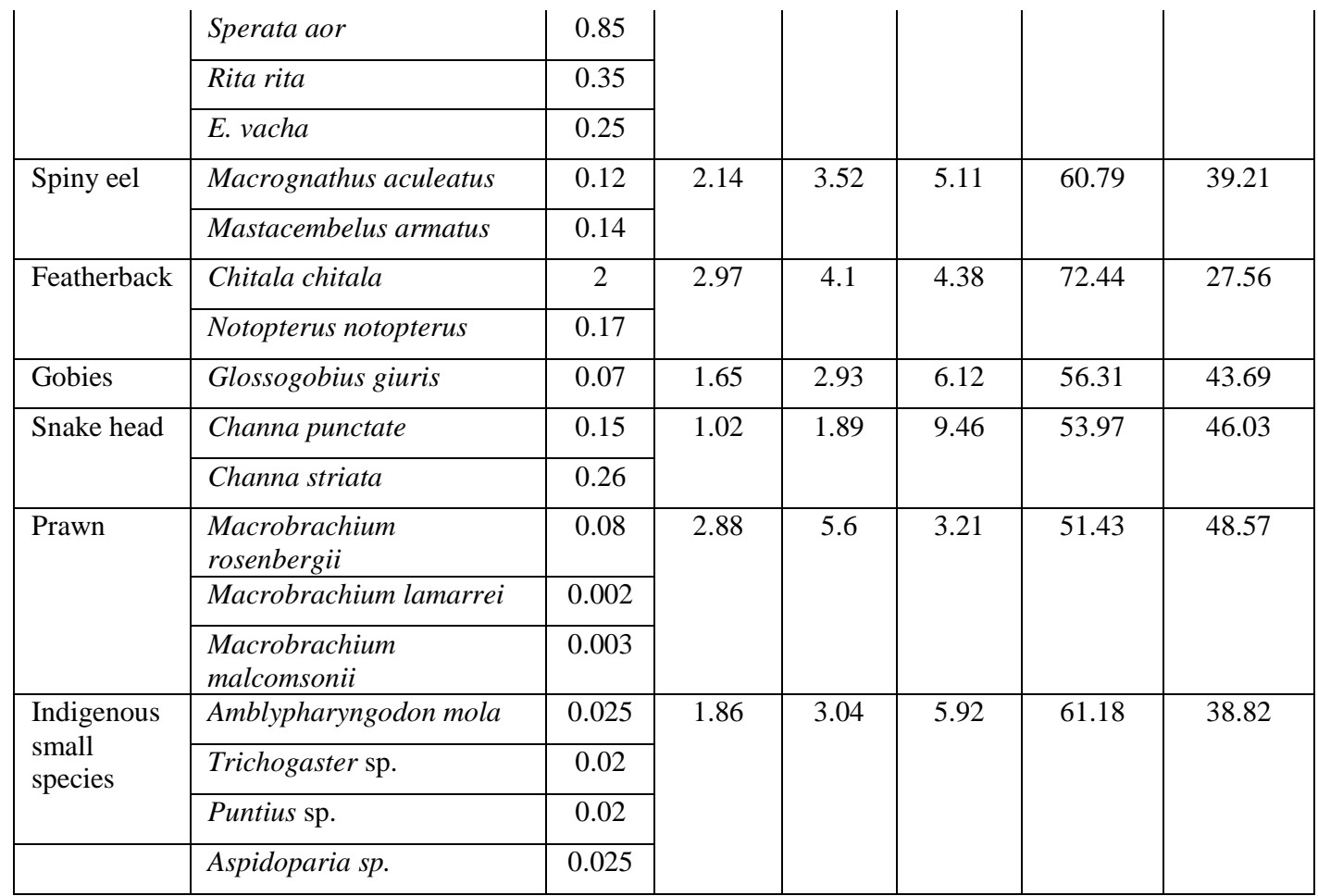

drainage system should be improved in a planned way, hygienic condition must be ensured, sufficient auction and retail places should be ensured, digital weighing system should be introduced, fish traders should be trained for proper fish handling procedure, government run fish transportation system with proper storage facilities should be introduced.

\section{Acknowledgements}

We express our gratitude to (i) local fishermen/fish producers, middlemen, consumers (Rajshahi, Bangladesh) for their assistance during data collection, (ii) coauthor Md. Akhtar Hossain, Masters of Science, Part-II for his efforts during data collection, and (iii) Dr. Khan Mohammad Iqbal, Laboratory of Aquatic Resource Science, Faculty of Fisheries, Kagoshima University for his useful and constructive comments.

\section{References}

Ahmed, M., A. Rab and M.P. Bimbao 1993. Household socioeconomics, resource use and fish marketing in two thanas in Bangladesh. ICLARM Tech. Rep., 40.82 pp.

Alam, J.M., R. Yasmin, A. Rahman, N. Nahar, N.I. Pinky, M. Hasan 2010. A Study on Fish Marketing System in Swarighat, Dhaka, Bangladesh. Nature and Science 8(12): 96-103.

Ali, E.A., H.I.M. Gaya and T.N. Jampada 2008. Economic analysis of fresh fish marketing In maiduguri gamboru market and kachallari alau 
Md. Mosaddequr Rahman , Md. Akhtar Hossain , Fatematuzzhura, Shuraya Tasnoova, Ferdous Ahamed, Md. Yeamin Hossain and Jun Ohtomi / Our Nature (2012) 10: 128-136

dam landing site of Northeastern, Nigeria. Journal of Agriculture and Social Sciences 4: 23-6.

Bangladesh Bureau of Statistics (BBS) 2005. Population Census-2001, Community Series, Zila: Rajshahi. Dhaka, Bangladesh, Planning Division, Ministry of Planning. Government of the People's Republic of Bangladesh.

Bryceson, D.F. 1993. Liberalizing Tangamia food trade; Public and private faces of urban marketing policy 1939 - 1988 UNRISD James Carry, London.

Eyo, A.A. 1992. Utilization of freshwater fish species in Nigeria. In: Eyo, A.A. and A.M. Balogun (eds.), Proceeding of the 10th Annual Conference of the Fisheries Society of Nigeria. pp. 32-8.

Fisheries Resource Survey System (FRSS) 2012. Fisheries Statistical Yearbook of Bangladesh. Fisheries Resources Survey System (FRSS), Department of Fisheries, Bangladesh. Volume 28: $46 \mathrm{p}$.

Hussain, S.A., H. Badar and S.B. Khokhar 2003. Market Intermediaries and Their Marketing Margins for Inland Fish - A Case Study of Lahore District. International Journal of Agriculture and Biology 5 (1): 73-76.
Kohl, R.L. and J.N. Uhl 1972. Marketing of Agricultural Products. 5th Ed., Macmillan Publishing Co., Inc. New York.

Mazid, M.A. 1994. Proc. SAARC workshop on fisheries socioeconomics and marketing. BARC, Dhaka.

Olukosi, J.O. and S.U. Isitor 1990. Introduction to Agricultural Marketing and Prices; Principles and Application. Living books series GU publications, Abuja, Nigeria.

Rahman, A.K.A. 1997. Fish Marketing in Bangladesh: Status and Issue. The University Press Ltd. Dhaka, Bangladesh. pp. 99-114.

Rahman, M.M., M.M. Hossain, S.M. Rahman and M.H. Alam 2009. Fish Marketing System in Khulna, Bangladesh. Journal of Innovation and Development Strategy 3(5): 27-31.

Shepherd, W.A 1996. A guide to marketing costs and how to calculate them. Marketing and Rural Finance Service, Agricultural Services Division. FAO. Rome.

Tomek, W.G. and K.L. Robinson 1981. Agricultural Products Prices, $2^{\text {nd }}$ edition. Ithaca, New York, U.S.A Cornel University Press. 